GLOBAL CHILD HEALTH

\title{
Beyond Bellagio: addressing the challenge of sustainable child health in developing countries
}

\section{Z A Bhutta}

Arch Dis Child 2004;89:483-487. doi: 10.1136/adc.2003.045732

Despite the hype and ostensible investments in child survival strategies, the state of child health in much of the developing world is alarming. Not only are global investments and support programmes for child health by the development agencies declining, but commensurate support for maternal and child health by poor countries themselves is poor. In order to make a meaningful contribution to maternal and child health and survival, a multi-pronged approach is needed which not only focuses on the proximal determinants of child health but also some of the underlying factors governing the status of women in society and expenditures on health and development.

Correspondence to: Professor Z A Bhutta, The Husein Lalii Dewraj of Paediatrics \& Child Health, The Aga Khan University, Karachi 74800, Pakistan; zulfiqar.bhutta@aku.edu

Accepted 2 December 2003
$\mathrm{D}$ espite tall claims to the contrary, a recent comprehensive evaluation of child mortality indicates that almost 11 million children under 5 years of age die annually. Nearly all of these deaths are concentrated in the world's poorest countries in sub-Saharan Africa and South Asia and 42 countries are alone responsible for $90 \%$ of these deaths. ${ }^{1}$

\section{CHILD SURVIVAL: A REVOLUTION THAT WAS NOT}

Earlier this year a group of global child health experts working on these issues met at a workshop in Bellagio, Italy. These scientists, speaking as individuals concerned with child health, produced the series of five articles on child health. ${ }^{1-5}$ The salient points raised by the "Bellagio Child Survival study group" (thereafter called the Bellagio group) indicated that diarrhoea, pneumonia, and neonatal causes of death were of global importance, with malaria and HIV infections responsible for a large number of deaths in some countries of Africa and Asia. The evidence also indicates that within each country, children from the poorest families are most likely to die and that socioeconomic inequalities impacted on child health and survival through multiple pathways. The impact of this unequal distribution of disease burden is compounded by ineffective and dysfunctional health systems that do not reach the poor. Notwithstanding the above, it was also indicated that if service delivery mechanism could be found, effective low cost interventions were available today that could potentially prevent two thirds of these deaths. Simple low cost interventions such as oral rehydration therapy and childhood vaccinations, have the greatest life saving potential but were yet unavailable in many deprived settings. The group concluded by highlighting that the momentum for the child survival revolution of the 1980s had slacked prematurely, thus leading to an arrest in the decline of child mortality and actual reversal of earlier gains in several cases. The Bellagio group made a passionate plea for several initiatives including significantly increased international funding for child health, global leadership in child health, and an action plan to translate knowledge into practice.

\section{WHY HAS SO LITTLE CHANGED?}

Child survival is one of the most pressing moral dilemmas of this century and the Bellagio consultation and papers were a timely reminder of unfinished business and the tasks ahead. Understandably, the major targets of the Bellagio group were the global development agencies and donor community. However, this paper will highlight some additional issues that lie at the core of the child survival debate which were not covered in the Bellagio series.

In order to support some of the points made in this paper, we undertook an empirical assessment of available health, human development, and economic indicators from 60 countries representing the top, middle, and bottom thirds of global child mortality. ${ }^{67}$ Table 1 lists the countries that form the basis of this analysis.

\section{Link of poverty and child health}

The importance of inequality and inequity (an unfair inequality) in health is well recognised ${ }^{8}$ and in many parts of the world this may also reflect gender inequity. ${ }^{9}$ Much of the burden of child mortality in the developing world lies within countries crippled by the burden of debt and stagnant economies. In the 1990s, the per capita GDP of developing countries grew by 1.6 per cent a year. But these slow gains were unevenly distributed. The per capita GDP growth of the poorest countries in the 1990s was slower than in the 1980s. The economic and health gap between rich and poor countries has thus consequently widened. ${ }^{4}$ Currently it is estimated that three billion people live on less than $\$ 1.3$ per day. This number is approximately the same as the additions to world population since $1960 .{ }^{10}$ Of the 4.4 billion people who live in developing countries, $60 \%$ lack access to sanitation, 33\% lack clean water, $20 \%$ have no health care, and $20 \%$ do not have enough dietary energy and protein. The world's 225 richest people have a combined wealth equivalent to the annual income of the poorest 2.5 billion people, nearly half of the 


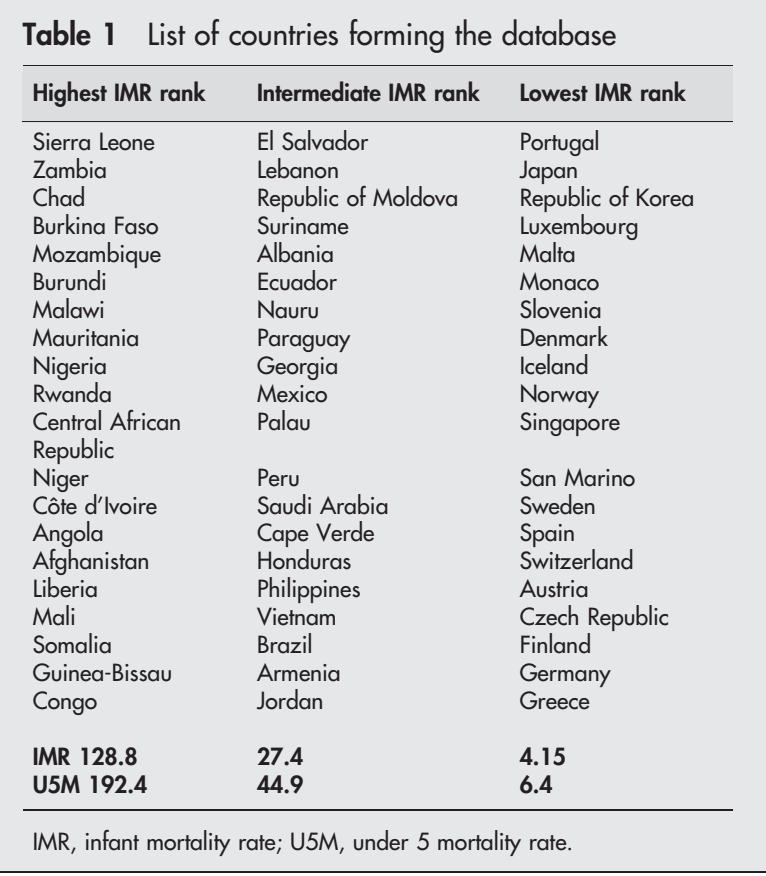

world's population. ${ }^{11}$ However, it is important to underscore that inequity does not lie between nations alone and that in contrast with available data on income differentials, within-country variation is the source of most inequality, rather than the differences between countries. ${ }^{12}$ This growing gap between the haves and have-nots is one of the root causes of social unrest and turmoil in much of the developing world.

In the words of Kaiser Bengali, a prominent social scientist in Pakistan:

\begin{abstract}
"Unequal societies are unjust societies. And unjust societies lose their moral and political legitimacy. While poverty causes hardship and deprivation for those caught in the poverty web, inequality causes a sense of grievance and injustice, promotes despondency and anger, and generates social and political instability and even violence." ${ }^{\prime \prime 3}$
\end{abstract}

Figure 1 indicates the relative debt burden, economic indicators and growth performance of the three groups of countries evaluated. Despite perfunctory gestures as to debt write off and reduction for the world's poorest countries, there has been little progress in actual terms. It is not that these gestures are economically impossible or unfeasible. Ironically, the largest quantum of debt write-off offered in recent decades has been in the form of largesse for supporting the "right side" in major conflicts (as in the case of Egypt and Turkey) and not due to societal needs. In the four years since Sir Shridath Ramphal, the former Secretary General of the Commonwealth stated that "debt has a child's face", ${ }^{14}$ there has been little improvement in the way that the wealthy nations of the world or indeed the financial institutions that control global economy, configure debt relief and structural adjustment programmes. The latter have been shown to actually increase poverty and disproportionately affect poor women and children in societies where safety nets are lacking. ${ }^{15}{ }^{16}$ Thus without addressing the core issue of social justice, equity, and pragmatic poverty reduction strategies, sustainable improvement in child health in poor countries is impossible.

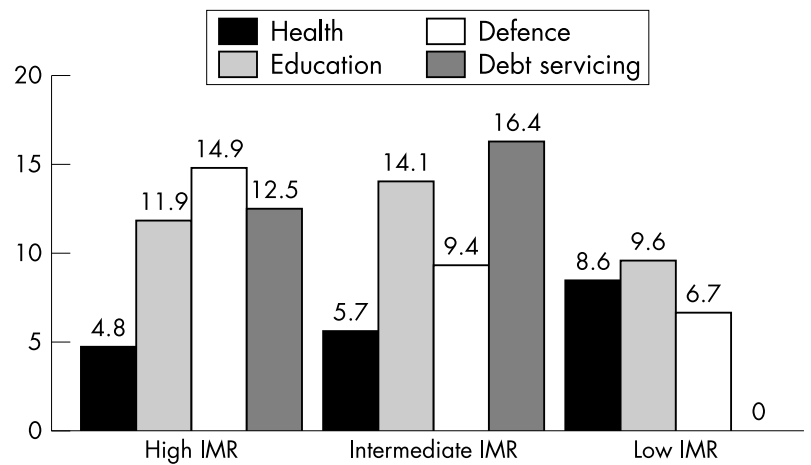

Figure 1 Comparative spending data in relation to infant mortality grouping. Health, education and defence spending (\% of central government expenditure 1992-2001). Debt servicing (as \% of exports of goods and services in 2000).

\section{Child health, population growth, and human development}

It is important to view child health and survival in the context of overall social development in society. ${ }^{17}$ This includes opportunities for education, sustainable livelihood and economic opportunities, and fertility regulation. The latter is of particular importance in developing countries as it can be shown that at least half of all improvement in economic growth attributable to population factors has come from fertility reduction and the rest from mortality declines. ${ }^{10}$ In the absence of such a holistic view of child health and development, one runs the risk of "entrapment". ${ }^{18}$ As a case study it has been stated that had it not been for AIDS, the gains in child survival in Malawi would have led to an unsustainable increase in population and food insecurity. ${ }^{19} \mathrm{~A}$ careful study of some of the most successful examples of primary care and child survival globally such as Cuba, Sri Lanka, and Kerala, reveals that concomitant with strategies for primary child health there were notable concomitant investments in education especially female literacy, family planning, and agrarian reform. Conversely it can be argued that an important reason for the relatively slow improvement in child health indicators in South Asia has been its burgeoning population which effectively wipes out any impact of health interventions. Figure 2 compares the relative fertility and growth rates among the three groups of countries with varying infant mortality rates.

\section{Local investments and national responsibility}

While there is little debate on the collective global responsibility for improving child health in developing countries,

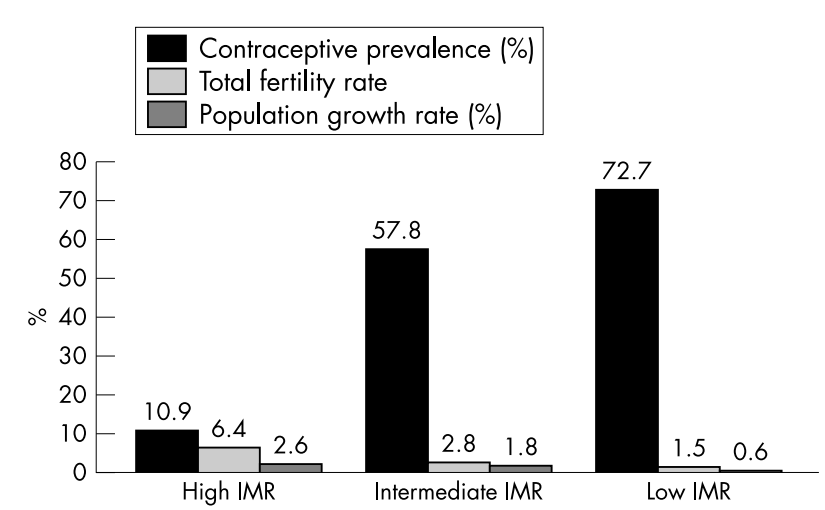

Figure 2 Relation of population growth, fertility regulation, and child mortality. 
few talk about national responsibility and the need for indigenous investments in primary health care. While poverty and debt servicing may impede sufficient investments in this regard, there are several examples where available resources have been wasted or pilfered. Nigeria is a case in point and stands as a living example that without good governance and honest political leadership, even an oil exporting country can squander available material resources and manpower. It is important to underscore issues of governance and corruption in the health system in many developing countries that have the poorest health indicators. Figure 3 indicates the available data on corruption perception index and defence spending for various groups of countries based on a recent assessment by Transparency International. ${ }^{20} \mathrm{~A}$ major reason for this haemorrhage of resources in some of the poorest nations of the world is to maintain successive generations of dictators, warlords, and despots in power. The power structures in such societies disproportionately favour the ruling classes and armed forces, with scant regard for primary care and maternal and child health $(\mathrm{MCH})$. To illustrate, at the height of the power of the Taliban in Afghanistan, while malnutrition among women and children in Afghanistan was rife, it was impossible to find a malnourished Taliban soldier. ${ }^{21}$

If sustainable gains in child health are to be found in Africa and Asia, there must be both an investment in grass root democracies that represent the rights and wishes of the people, and also in dismantling the feudal power structures that have a vested interest in maintaining the status quo. ${ }^{14}$ It must be underscored that while Ministries of Health in developing countries have the principal responsibility for primary care and health, it is the Ministry of Finance that holds the main purse-strings and determines priorities and investments. The decision making process in this regard and indeed the relation of democracy and investment in primary health care and human development has been poorly studied.

\section{War, conflict, and child health}

Figure 3 also indicates relative levels of military spending (as a proportion of health budgets) in the three groups of countries evaluated. As can be seen, there is a disproportionate amount of spending of arms in poor countries. Although global arms suppliers should be held accountable for this anomaly, ${ }^{22}$ the final responsibility for this wanton waste of meagre resources is at the end local. It has been estimated that African states themselves spend almost \$22 million annually on purchasing arms and the probable

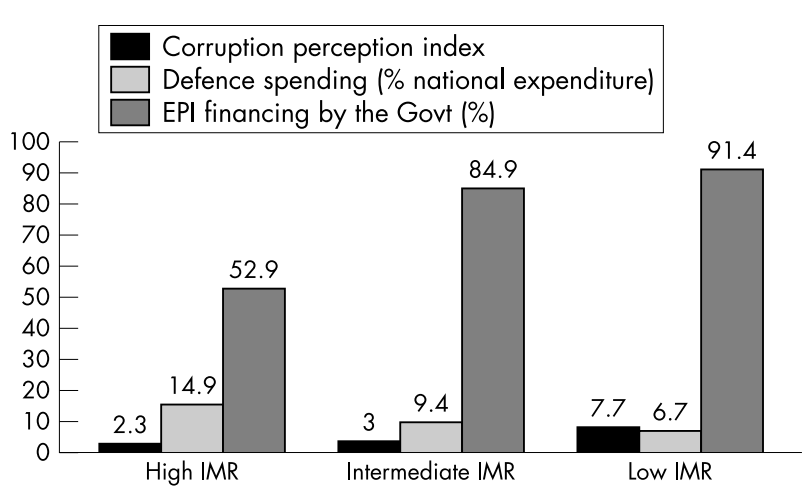

Figure 3 Comparison of indigenous Expanded Programme for Immunisation (EPI) financing (\%), corruption perception indices, and defence spending. The corruption perception index score relates to perceptions of the degree of corruption as seen by business people and risk analysts, and ranges between 10 (highly clean) and 0 (highly corrupt). IMR, infant mortality rate. economic losses due to conflict in Africa amount to almost $\$ 15$ billion. $^{23}$ In the case of India and Pakistan, involved in one of the most expensive and prolonged high altitude conflicts over the last 20 years, this waste of meagre resources is even more incomprehensible. It has been estimated that the Siachen conflict over a desolate icy wasteland, costs India and Pakistan an average of $\$ 200$ million annually, more than enough to meet the primary child health needs for several states and provinces in the region. This wanton spending on arms pales in comparison with the costs of developing an arsenal of nuclear weapons and sophisticated missile technology in south Asia. ${ }^{24}$ Ironically, one of the most poignant statements against the global proliferation of arms trade was made by a sitting US president who had led the Allied armies in the second world war:

"Every gun that is made, every warship launched, every rocket fired, signifies in the final sense a theft from those who hunger and are not fed, those who are cold and are not clothed." 25

Today the same superpower leads the world in arms sales to the developing world, in many instances to despotic rulers and governments that have little interest in the wellbeing of their populace.

The world has seen much misery over the past few decades in almost all parts of the developing world. These have ranged from smouldering conflicts in the Middle East, Africa, Afghanistan, Kashmir, and even close to the heart of Europe in the Balkans. A large number of silent and unheard victims of these conflicts are the poor women and children of these regions. While a few instances find their way to the social conscience of the world, the majority suffer in silence and die unsung. The first few days of the recent Afghan and Iraq conflicts saw a disproportionate number of child deaths which were largely dismissed as "collateral damage". ${ }^{26}{ }^{27}$ The point being that unlike the safe guards provided by the Geneva Convention for combatants, there are few safeguards protecting the rights of women and children in war. The landmark report by Graca Machel on children and war has yet to find its way into the global conscience as fundamental principles of child rights. ${ }^{28}$

\section{Lack of integration of maternal and child health}

The health of the mothers and infants are closely intertwined and in general both correlate closely within developing

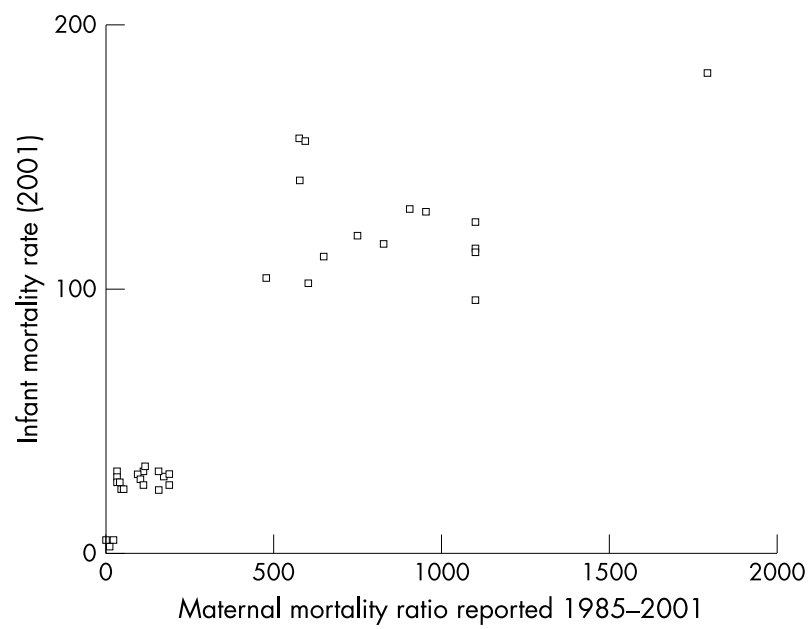

Figure 4 Comparison of maternal mortality and infant mortality indicators. 
Table 2 Millennium development goals

\begin{tabular}{|c|c|c|}
\hline & & The global challenge \\
\hline 1 & Eradicate extreme poverty and hunger & $\begin{array}{l}\text { Target for 2015: Halve the proportion of people living on less than a dollar a day and those who suffer from } \\
\text { hunger }\end{array}$ \\
\hline $\begin{array}{l}2 \\
3\end{array}$ & $\begin{array}{l}\text { Achieve universal primary education } \\
\text { Promote gender equality and empower } \\
\text { women }\end{array}$ & $\begin{array}{l}\text { Target for 2015: Ensure that all boys and girls complete primary school } \\
\text { Targets for } 2005 \text { and } 2015 \text { : Eliminate gender disparities in primary and secondary education preferably by } \\
2005 \text {, and at all levels by } 2015\end{array}$ \\
\hline 4 & Reduce child mortality & Target for 2015: Reduce by two thirds the mortality rate among children under 5 \\
\hline 5 & Improve maternal health & Target for 2015: Reduce by three quarters the ratio of women dying in childbirth \\
\hline 6 & $\begin{array}{l}\text { Combat HIV/AIDS, malaria, and other } \\
\text { diseases }\end{array}$ & $\begin{array}{l}\text { Target for 2015: Halt and begin to reverse the spread of HIV/AIDS and the incidence of malaria and other } \\
\text { major diseases }\end{array}$ \\
\hline 7 & Ensure environmental sustainability & $\begin{array}{l}\text { Targets: } \\
\text { - Integrate the principles of sustainable development into country policies and programmes and reverse the } \\
\text { loss of environmental resources } \\
\text { - By } 2015 \text {, reduce by half the proportion of people without access to safe drinking water } \\
\text { - By } 2020 \text { achieve significant improvement in the lives of at least } 100 \text { million slum dwellers }\end{array}$ \\
\hline 8 & $\begin{array}{l}\text { Develop a global partnership for } \\
\text { development }\end{array}$ & $\begin{array}{l}\text { Targets: } \\
\text { - Develop further an open trading and financial system that includes a commitment to good governance, } \\
\text { development, and poverty reduction-nationally and internationally } \\
\text { - Address the least developed countries' special needs, and the special needs of landlocked and small } \\
\text { island developing states } \\
\text { Deal comprehensively with developing countries' debt problems } \\
\text { - Develop decent and productive work for youth } \\
\text { - In cooperation with pharmaceutical companies, provide access to affordable essential drugs in } \\
\text { developing countries } \\
\text { In cooperation with the private sector, make available the benefits of new technologies-especially } \\
\text { information and communications technologies }\end{array}$ \\
\hline
\end{tabular}

countries (fig 4). However, despite this awareness there are few examples of integrated maternal and child health programmes and the child survival programme also ignored the important contribution of maternal health to survival of infants. It is now apparent that almost half of all infant deaths in most developed countries occur in the neonatal period and little progress can be made without an integrated programme of $\mathrm{MCH}$. However, such programmes are the exception rather than the norm in developing countries and in particular the integration of $\mathrm{MCH}$ and family planning services is poor. The link between fertility regulation through support of contraceptive use and breast feeding support and child survival is well established. ${ }^{29}$

CAN SOMETHING BE DONE AND WHO WILL DO IT? The doom and gloom scenario painted above is neither hopeless nor inevitable. However, unless the root causes of global inequity in child health are addressed, mere superficial short term solutions will do nothing to change the status quo.

\section{Increased allocations to maternal child health and integrating services}

The Bellagio group highlighted a number of measures that are necessary to ensure that sufficient resources are allocated to supporting child health globally. The yearly cost of scaling up vaccinations, treating childhood illnesses, and preventing and treating malaria has been cited at under $\$ 8$ billion. ${ }^{5}$ In mere economic terms this is minuscule compared to what Africa spends on arms purchase annually and \$1 billion spent on carpet bombing the rubble of Afghanistan. Both developed and developing countries facing the shameful statistics of MCH and survival, need to divert much more resources towards primary health care. The global burden of debt accumulated by the poorest countries must be reduced forthwith and developing countries spending under $2 \%$ of their GDP on health must be encouraged to at least double this figure.

\section{Political will and leadership for $\mathrm{MCH}$}

There is a crisis of global leadership in child health and few towering personalities who can generate and garner support and the political will to produce real change. ${ }^{30}$ However, it is necessary that this be done and developed as a concerted MCH programme that can be sustained and does not focus on mortality reduction alone. This will necessitate involving representatives of civic societies and local government in planning and developing this agenda. This new $\mathrm{MCH}$ programme must be broader than health issues alone and also focus on development outcomes. Adequate nutrition and attention to essential maternal and child rights are key in this effort. Table 2 summarises the relevant millennium development goals that aim to address major issues in $\mathrm{MCH}$. While most countries have signed up to these it is highly unlikely that these targets will be met without a major change in strategies.

\section{Innovative solutions and a primary care focus for interventions}

It is notable that there is sufficient knowledge and evidence of what works to save almost $70 \%$ of all children under 5 in the world. ${ }^{2}$ However, it is unclear if we know enough to reduce morbidity and provide the prerequisites for adequate child nutrition and development for all children who need it. There is increasing recognition of the importance of early childhood development ${ }^{31}$ and the need for more targeted research to find solutions that work in diverse settings. The recent recognition that adequate basic primary care interventions can also be provided by community health work$\operatorname{ers}^{32}{ }^{33}$ offers some hope that care can actually reach those need it the most. Given the importance of the early neonatal period to survival in infancy, it is critically important that the focus remains on integrated maternal and child management strategies and training of a common cadre of community health workers. ${ }^{33}$

\section{The potential role of academic and professional bodies}

In the entire recent debate on global child health, the role of professional and academic bodies representing paediatricians has been variable. While some have actively taken the challenge and developed an international child health strategy, others have failed to mainstream the special role that child health professionals can play in the global context. 
This role can range from active advocacy to actual support and voluntary service in deprived settings. In other instances partnerships with local child health professionals may be the most logical way to combine efforts. Given increasingly shrinking boundaries in a globalising world this is no longer charity or mere humanitarianism, but an ethical imperative.

\section{REFERENCES}

1 Black RE, Morris SS, Bryce J. Where and why are 10 million children dying every year? Lancet 2003;361:2226-34.

2 Jones G, Steketee RW, Black RE, et al. How many child deaths can we prevent this year? Lancet 2003;362:65-71.

3 Bryce J, Arifeen S, Pariyo G, et al. Reducing child mortality: can public health deliver? Lancet 2003;362:159-64.

4 Victora CG, Wagstaff A, Schellenberg JA, et al. Applying an equity lens to child health and mortality: more of the same is not enough. Lancet 2003;362:233-41.

5 The Bellagio Child Survival Study Group. Knowledge into action for child survival. Lancet 2003;362:323-7.

6 The World Bank. World development indicators 2003. Washington DC.

7 UNICEF. State of the world's children 2003. New York.

8 Feachem RGA. Poverty and inequity: a proper focus for the new century. Bull World Health Organ 2000;78:1-2.

9 Sen G, George A, Östlin P, eds. Engendering international health-the challenge of equity. Cambridge: MIT Press, 2002.

10 United Nations. The state of the world's population. United Nations Population Fund, 2002.

11 Waterston T. Inequity in child health as a global issue. Pediatrics 2003;112(3 part 2):739-41.

12 Pradhan M, Sahn DE, Younger SD. Decomposing world health inequality. $J$ Health Econ 2003;22:271-93.

13 Bengali K. Creating an unequal society Daily Dawn. Karachi, 8 August 2002. www.dawn.com/2002/08/10/op.htm\#2. Accessed 20 October 2003.

14 Ramphal S. Commentary. Debt has a child's face. The progress of nations. New York: UNICEF, 1999

15 Bhutta ZA. Structural adjustments and impact on health and society. Int J Epidemiol 2001;30:712-16.

16 Costello A, Watson F, Woodward D. Human face or human facade. The effects of adjustment on the health of mothers and children in developing countries. Working Paper Institute of Child Health. http:// www.cich.ich.ucl.ac.uk.

17 Alistair W, Hales S, Litidamu N, et al. Protecting human health in a changing world: the role of social and economic development. Bull World Health Organ 2000;78:1148-54.

18 King $M$, Elliott C. To the point of farce: a Martian view of the Hardinian taboo-the silence that surrounds population control. BMJ 1997:315:1441-3.

19 Mola G, Thornton J, Breen M, et al, eds. Primary mother care and population. Stamford, CA: Speigel, 2003.

20 Transparency International. Corruptions Perception Index 2003. London. http://www.transparency.org/pressreleases archive/2003/ 2003.10.07.cpi.en.html. Accessed 20 October 2003.

21 Bhutta ZA. Children of war: the real casualties of the Afghan conflict. BM 2002;324:349-52.

22 Southall DP, O'Hare BAM. Empty arms: the effect of the arms trade on mothers and children. BMJ 2002;325:1457-61.

23 Mulama J. Poverty, insecurity fuel the arms trade in Africa. Daily Dawn 11 October 2003:14. http:www.dawn.com/2003/10/11/intl4.htm. Accessed 20 October 2003.

24 Bhutta ZA, Nundy S. Thinking the unthinkable; walking the nuclear tightrope in South Asia. BMJ 2002;324:1405-6.

25 President Dwight D Eisenhower (1890-1969). Speech, 16 April 1953 Washington DC, to the American Society of Newspaper Editors. The Chance for Peace, Public Papers of the Presidents of the United States, 1960.

26 Traynor I. Afghans are still dying as air strikes go on. But no one is counting. The Guardian, 12 February 2002, London.

27 Bhutta ZA. Who speaks for the children of Iraq? Issues in Medical Ethics 2003;11:36-7.

28 Machel G. Impact of armed conflict on children. New York: United Nations and UNICEF, 1996

29 Rutstein S. Effect of birth intervals on mortality and health. Calverton, MD: Measure/DHS+, Macro International, Inc, 2000:65.

30 Bhutta ZA. Values and leadership. Global leadership is in disarray. BMJ 2003;326:657

31 Young ME. Early childhood development: investing in the future. The World Bank, 2000.

32 Oxford Policy Management Group. Lady Health Worker Programme. External evaluation of the National Programme for Family Planning and Primary Health care. Final Report. Government of Pakistan, March 2002.

33 Bang AT, Bang RA, Baitule SB, et al. Effect of home-based neonatal care and management of sepsis on neonatal mortality: field trial in rural India. Lancet 1999:354:1955-61.

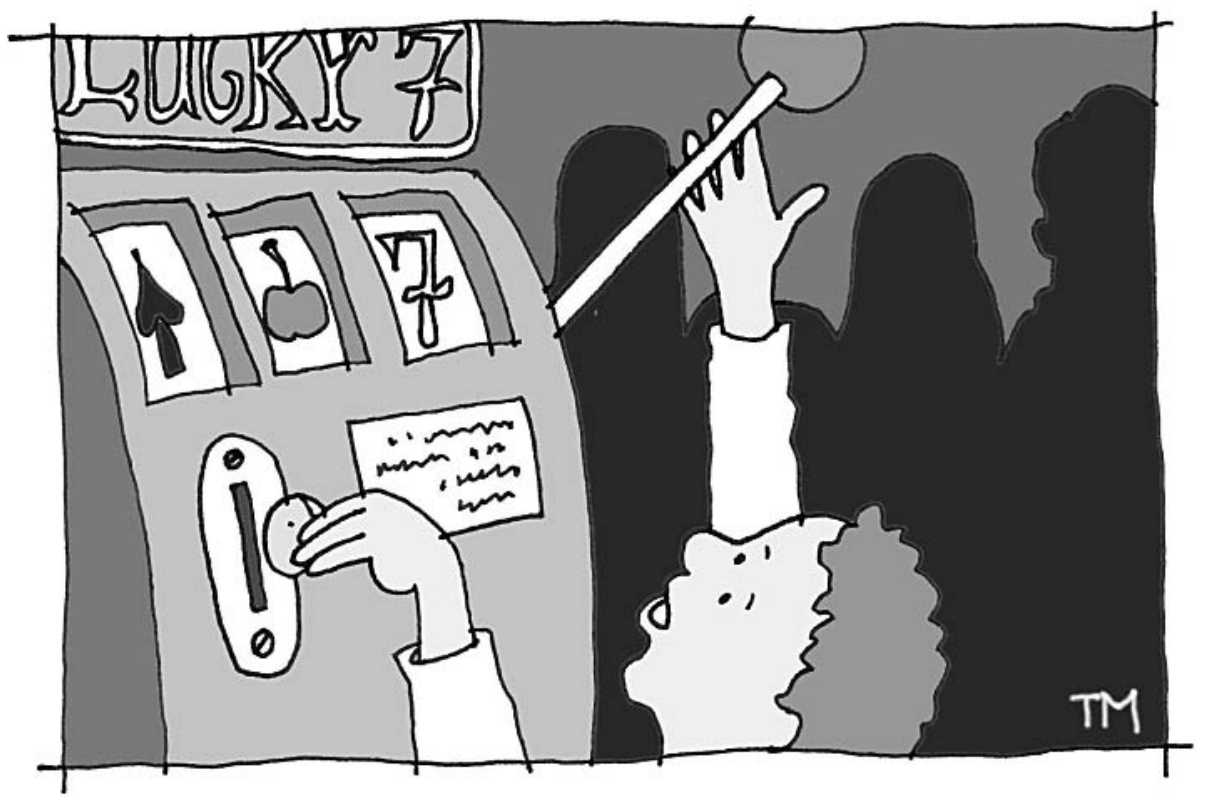

